\title{
Influence of the Immersion Time and Temperature on the Corrosion of API X52 Steel in an Aqueous Salt Medium
}

\author{
Mónica Corrales-Luna ${ }^{1}$, O Olivares-Xometl ${ }^{2, *}$, Natalya V Likhanova ${ }^{3}$, Raquel E. Hernández Ramírez ${ }^{4}$, \\ Irina V. Lijanova ${ }^{5}$, P Arellanes-Lozada ${ }^{2}$, Elsa Arce Estrada ${ }^{1}$ \\ ${ }^{1}$ Instituto Politécnico Nacional, ESIQIE, Departamento de Metalurgia y Materiales, Av. Instituto \\ Politécnico Nacional S/N, Col. Lindavista, México D.F. 07300, México. \\ ${ }^{2}$ Benemérita Universidad Autónoma de Puebla, Facultad de Ingeniería Química, Av. San Claudio, \\ Ciudad Universitaria. Col. San Manuel, Puebla, Pue. 72570, México. \\ ${ }^{3}$ Instituto Mexicano del Petróleo, Gerencia de Ingeniería de Recuperación Adicional, Eje Central \\ Lázaro Cárdenas No. 152, Col. San Bartolo Atepehuacán, México D.F. 07730, México. \\ ${ }^{4}$ Tecnológico de Estudios Superiores de Coacalco, 16 de Septiembre 54, Col. Cabecera municipal, \\ Coacalco de Berriozábal, 55700, Estado de México, México. \\ ${ }^{5}$ Instituto Politécnico Nacional, CIITEC, Cerrada Cecati S/N, Colonia Santa Catarina, Azcapotzalco, \\ México D.F. 02250, México. \\ *E-mail: oxoctavio@yahoo.com.mx
}

doi: $10.20964 / 2017.07 .12$

Received: 17 March 2017 / Accepted: 30 April 2017 / Published: 12 June 2017

Surface analyses aimed at assessing the corrosion damage suffered by API 5L X52 steel as a result of long immersion times in an aqueous salty medium (ASM), in absence and presence of oxygen, were carried out. The ASM chemical analyses revealed high concentrations of inorganic and organic ions, which evidenced a highly corrosive medium. The characterization of the corrosion products formed after 60 days exposing the steel sample to the ASM was performed by X-ray photoelectron spectroscopy (XPS), which confirmed the presence of different iron oxide faces. The modeling of electrochemical impedance spectroscopy (EIS) spectra showed that the electric charge transfer is a function of the temperature and immersion time used to expose the steel sample to the aqueous medium. Finally, the SEM/EDX analyses confirmed the combined presence of a not-compact film with corrosion products and salts on the surface, having as a result, an irregular and porous surface topography.

Keywords: Carbon steel; Corrosion behavior; EIS; XPS; SEM

$\underline{\text { FULL TEXT }}$ 
(C) 2017 The Authors. Published by ESG (www.electrochemsci.org). This article is an open access article distributed under the terms and conditions of the Creative Commons Attribution license (http://creativecommons.org/licenses/by/4.0/). 